\title{
Epidemiology and phylogenetic analysis of Taura syndrome virus in cultured Pacific white shrimp Litopenaeus vannamei B. in Taiwan
}

\author{
LiTing Cheng ${ }^{1}$, Wen-Hui Lin ${ }^{2,4}$, Pei-Chyi Wang ${ }^{2,3}$, Ming-An Tsai ${ }^{2}$, Ping-Yueh Ho $^{2}$, \\ Jung-Pin Hsu ${ }^{4}$, Red-Shyong Chern ${ }^{2}$, Shih-Chu Chen ${ }^{1,2, *}$ \\ ${ }^{1}$ Graduate Institute of Animal Vaccine, ${ }^{2}$ Department of Veterinary Medicine, ${ }^{3}$ Department of Tropical Agriculture and \\ International Cooperation, National Pingtung University of Science and Technology, Pingtung 91201, Taiwan \\ ${ }^{4}$ Present address: Pingtung Hsien Livestock Disease Control Center, Pingtung, Taiwan
}

\begin{abstract}
Taura syndrome virus (TSV) has spread worldwide, causing significant economic losses since Taura syndrome was first described in Ecuador in 1992. To determine the prevalence and impact of TSV infection on the shrimp farming industry in Taiwan, Pacific white shrimp Litopenaeus vannamei B. were collected from 220 farms between 2004 and 2006 for viral detection by reverse transcription polymerase chain reaction. Data showed that the overall TSV prevalence rate was $20 \%$ (43/220 farms). Comparing shrimp growth stages, TSV prevalence rates were $4 \%$ for postlarvae, $24 \%$ for juveniles, $24 \%$ for subadults, $32 \%$ for adults, and $5 \%$ for brooders. Among TSV-positive farms, average infection incidence was $35 \%$ in postlarvae farms, $55 \%$ in juvenile farms, $39 \%$ in subadult farms, $31 \%$ in adult farms, and $20 \%$ in brooder farms. Notably, TSV was also detected in Exopalaemon orientis H. from 1 of 10 farms. Tail fans and appendages had red pigmentation, which is characteristic of TSV infection. Of shrimp with pathological lesions, $100 \%$ had lesions on tail fans, $88 \%$ on appendages, and $80 \%$ in gills. Sequence comparison using the TSV VP1 (structural protein) gene showed that 9 isolates from the farms had 92.3 to 99.5\% nucleotide sequence identity with strains in the GenBank database from Taiwan (AF406789 and AY355310) and Venezuela (DQ212790). This is the first broad epidemiological study of TSV infection in L. vannamei in Taiwan.
\end{abstract}

KEY WORDS: Taura syndrome virus $\cdot$ Litopenaeus vannamei $\cdot$ Taiwan

\section{INTRODUCTION}

High-density farming is common in the shrimp aquaculture industry. However, such practice allows pathogens to spread rapidly throughout farms, resulting in considerable economic losses. Taiwan became a major producer of Penaeus monodon F. in the 1980s, with production peaking at 95000 metric tons in 1987 (Liao 1989). However, during 1987 to 1991, a combined viral and protozoan infection devastated farm crops, dramatically reducing production. Pacific white shrimp Litopenaeus vannamei B. was imported to Taiwan from Hawaii and Latin America as a replacement crop in 1997. Production of $L$. vannamei reached 12099 tons by 2005 (Fisheries Agency 2006). Because $L$. vannamei is accustomed to warm water temperatures, most farms are located in southern Taiwan (Pingtung, Kaoshiung, Tainan, and Chaiyi counties).

Although Litopenaeus vannamei is resistant to environmental stress factors and can adapt to a broad salinity range (Menz \& Blake 1980, Boyd 1989, Wyban et al. 1995, Kureshy \& Davis 2002), high-density farming increases the incidence of viral infections. Taura syndrome virus (TSV) and white spot syndrome virus affect white shrimp at various growth stages and cause significant economic losses (Lo \& Kou 1998). In- 
fection of $L$. vannamei by TSV has resulted in cumulative mortality rates of 40 to $90 \%$ (Hasson et al. 1995).

First isolated from white shrimp farms near the Taura River in Ecuador in 1992, TSV is a nonenveloped, single-stranded RNA virus classified as Cripavirus in the family Dicistroviridae (Mayo 2002, Wertheim et al. 2009). The icosahedral virion is roughly $32 \mathrm{~nm}$ in diameter, and the genome is approximately $10 \mathrm{~kb}$ long. TSV spreads rapidly within shrimp populations. Insects and birds may also contribute to the spread of the virus. The intestinal tract of Trichocorxareticulata may harbor TSV (Lightner et al. 1995), and gulls can carry and pass the virus in their feces (Garza et al. 1997). Infection of TSV can be separated into 3 phases. The acute phase (Days 1 through 7 post infection) is characterized by lethargy and loss of appetite. The most prominent characteristic of TSV infection is red pigment deposition on the surface of the shrimp, generating a dark-pink appearance, and the tail fan and appendages will appear especially red (Lightner et al. 1995, Tu et al. 1999). Most infected shrimp will die if ecdysis takes place during the acute phase. During the transition phase, typical TSV lesions are being resolved and black spots can be observed. During the chronic phase of the disease, shrimp appear grossly normal (Hasson et al. 1999), and horizontal transmission of TSV may occur (Overstreet et al. 1997).

We examined the epidemiology of TSV in Litopenaeus vannamei in Taiwan. Diagnosis of TSV infection can be done through pathological examination; however, polymerase chain reaction (PCR) remains the fastest and most sensitive method for virus detection (Nunan et al. 1998b, Poulos et al. 2008, Côté et al. 2009). Reverse-transcription PCR (RT-PCR) was performed to detect TSV presence in shrimp during various growth stages. To identify factors that may contribute to virus spread, crustacean and insect samples were also collected for TSV detection. Sequences of TSV isolates were compared. Analytical results such as prevalence rate and effects of environmental risk factors can be used as a reference for the industry's attempt to control TSV.

\section{MATERIALS AND METHODS}

\section{Sample collection}

Shrimps were collected from 220 farms in 4 counties (Pingtung, Kaoshiung, Tainan, and Chaiyi) in southern Taiwan between September 2004 and August 2006. We sampled 50 postlarvae farms, 50 juvenile farms, 50 subadult farms, 50 adult farms, and 20 brooder farms. A preliminary experiment detected TSV in 8/40 cases, resulting in an estimated TSV prevalence rate of $20 \%$. As at least 14 shrimp should be collected from each farm to ensure the presence of 1 positive case at the $95 \%$ confidence level, we randomly collected 20 shrimp from each farm to improve statistical accuracy (Daniel 2005). During sample collection, farmers were asked to estimate their shrimp mortality rate on the following scale: 0 , no obvious loss; 1, 1-25\% loss; 2, 26-50\% loss; 3, 51-75\% loss; 4, 76-100\% loss.

Since various organisms found in shrimp farms may harbor TSV, samples were collected for TSV detection. Copepods Calanus finmarchicus G. were collected from 20 shrimp farms (10 $\mathrm{g}$ from each farm). Shrimp Exopalaemon orientis H. (10 individuals from each farm) and larval samples from multiple dragonfly species (10 larvae from each farm) were also collected from 10 farms. Samples were washed in sterile, distilled water prior to DNA extraction for PCR analysis.

Samples of shrimp farm water were collected to determine ammonia (Ammonium Test; Merck), nitrite (Nitrite Test; Merck), and salinity levels.

\section{Pathology}

Shrimp tail fans, appendages, gills, and the hepatopancreas were examined for signs of TSV infection. Shrimp were fixed in Davidson's solution and processed for paraffin sectioning (Lightner 1996). Sections were stained with hematoxylin and eosin (H\&E).

\section{Reverse transcription polymerase chain reaction (RT-PCR)}

RNA was extracted from $200 \mu$ of shrimp tissue preparation (whole shrimp were used for postlarvae; appendages, gills, and tail fans were used for adults) using $0.8 \mathrm{ml} \mathrm{TRIzol}{ }^{\circledR}$ (Invitrogen) according to the manufacturer's instructions. Extracted RNA was dissolved in $65 \mu$ l of DEPC-treated water (Amresco). Samples of Calanus finmarchicus, Exopalaemon orientis and dragonfly larvae were processed in the same manner.

Primers employed for TSV detection were 9195F (forward: 5'-TCA ATG AGA GCT TGG TCC-3') and 9992R (reverse; 5'-AAG TAG ACA GCC GCG CTT$3^{\prime}$ ), with an expected product size of $231 \mathrm{bp}$ (Nunan 
et al. 1998a). The RT-PCR reaction mixture, containing $5 \mu$ l extracted RNA and 10 pmol of each primer, was subjected to 35 amplification cycles $\left(94^{\circ} \mathrm{C}\right.$ for $50 \mathrm{~s}, 55^{\circ} \mathrm{C}$ for $50 \mathrm{~s}$, and $72^{\circ} \mathrm{C}$ for $50 \mathrm{~s}$ ), following an initial $40 \mathrm{~min} \mathrm{RT}$ reaction at $42^{\circ} \mathrm{C}$.

For sequence comparison using the TSV VP1 gene, primers used were 55P1 (5'-GGC GTA GTG AGT AAT GTA GC-3') and 55P2 (5'-CTT CAG TGA CCA CGG TAT AG-3'), with an expected product size of 1303 bp. RT-PCR analysis was performed as described above. Products of RT-PCR were cloned into a commercial vector using the TOPO TA Cloning ${ }^{\circledR}$ Kit (Invitrogen) for sequencing following the manufacturer's instructions.

\section{Sequence comparison and statistical analysis}

Sequences of the TSV VP1 gene were compared to those in GenBank using SeqMan and MegAlign from DNASTAR (Lasergene). CLUSTAL X software (Molecular Evolutionary Genetics Analysis; www. megasoftware.net) was used with minimum evolution (ME; Rzhetsky \& Nei 1993), maximum parsimony (MP; Saitou \& Nei 1987), and neighbor-joining (NJ; Fitch 1971) algorithms for phylogenetic analysis. Evolutionary distance matrices for ME, MP, and NJ were generated (Jukes \& Cantor 1969), and tree topologies were examined by bootstrap analyses (Felsenstein 1985) based on 1000 resamplings. GraphPad Prism 2.01 software was used for statistical analysis of experimental data.

\section{RESULTS}

\section{Epidemiology}

Between September 2004 and August 2006, shrimp (20 from each farm) were collected from 220 farms to determine the prevalence of TSV infection in Litopenaeus vannamei in Taiwan. The presence of a $231 \mathrm{bp}$ RT-PCR product indicated positive cases (Fig. 1). TSV was detected in 43 of 220 farms for a $20 \%$ prevalence rate (Table 1). Prevalence rates of TSV in shrimp at different growth stages were as follows: postlarvae, $4 \%$; juveniles, $24 \%$; subadults, $24 \%$; adults, $32 \%$; brooders, $5 \%$ (Table 1).

The TSV-positive rate for each farm was determined, and the average TSV-

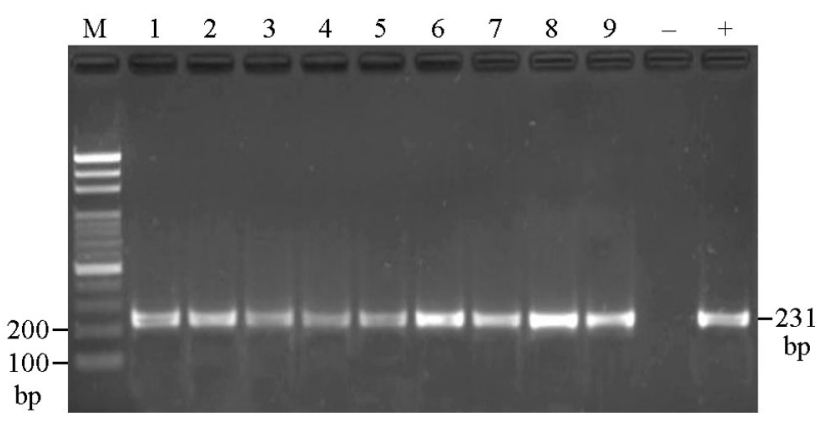

Fig. 1. Litopenaeus vannamei. Detection of Taura syndrome virus (TSV) in Pacific white shrimp by RT-PCR. M: 100 bp DNA ladder marker; lanes 1-9: PCR products from 9 different shrimp samples; - : negative control $;+$ : positive control

positive rate was $35 \%$ for postlarvae farms, 55\% for juvenile farms, 39\% for subadult farms, 31\% for adult farms, and $20 \%$ for brooder farms (Fig. 2A). Juvenile shrimp had the highest TSV infection rate, while older shrimp showed lower infection rates. These estimated mortality rates demonstrate that postlarvae shrimp had the highest death rate and brooder shrimp had the lowest death rate (Fig. 2B).

To examine whether seasons affect the TSV infection rate, TSV-positive rates for farms were reordered according to sample collection date. Winter (December-February) had the highest infection rate at $55 \%$. The TSV-positive rates for other seasons were $39 \%$ for spring (March-May), $35 \%$ for summer (June-August), and $23 \%$ for autumn (SeptemberNovember).

To determine whether pond water quality affects TSV prevalence, tests were performed to measure nitrite and ammonium concentrations in water. Of

Table 1. Litopenaeus vannamei. Detection of Taura syndrome virus (TSV) by RT-PCR in Pacific white shrimp at different growth stages. Shown are the numbers of TSV-positive shrimp farms/number of farms examined. nd: no data available

\begin{tabular}{|lccccccc|}
\hline $\begin{array}{l}\text { Sampling } \\
\text { location }\end{array}$ & $\begin{array}{c}\text { Postlarva } \\
(<1 \mathrm{~g})\end{array}$ & $\begin{array}{c}\text { Juvenile } \\
(1 \sim 3.9 \mathrm{~g})\end{array}$ & $\begin{array}{c}\text { Subadult } \\
(4 \sim 8.9 \mathrm{~g})\end{array}$ & $\begin{array}{c}\text { Adult } \\
(>9 \mathrm{~g})\end{array}$ & Brooder & $\begin{array}{c}\text { Total } \\
(\%)\end{array}$ \\
\hline Pingtung & $1 / 25$ & $9 / 20$ & $11 / 20$ & $11 / 20$ & $1 / 10$ & $\begin{array}{c}33 / 95 \\
(35)\end{array}$ \\
Kaohsiung & $1 / 25$ & $2 / 10$ & $1 / 10$ & $4 / 10$ & $0 / 10$ & $\begin{array}{c}8 / 65 \\
(12)\end{array}$ \\
Tainan & nd & $1 / 10$ & $0 / 10$ & $0 / 10$ & nd & $\begin{array}{c}1 / 30 \\
(3)\end{array}$ \\
Chiayi & nd & $0 / 10$ & $0 / 10$ & $1 / 10$ & nd & $\begin{array}{c}1 / 30 \\
(3)\end{array}$ \\
$\begin{array}{l}\text { Total } \\
(\%)\end{array}$ & $2 / 50$ & $12 / 50$ & $12 / 50$ & $16 / 50$ & $1 / 20$ & $\begin{array}{c}43 / 220 \\
(20)\end{array}$ \\
\hline
\end{tabular}



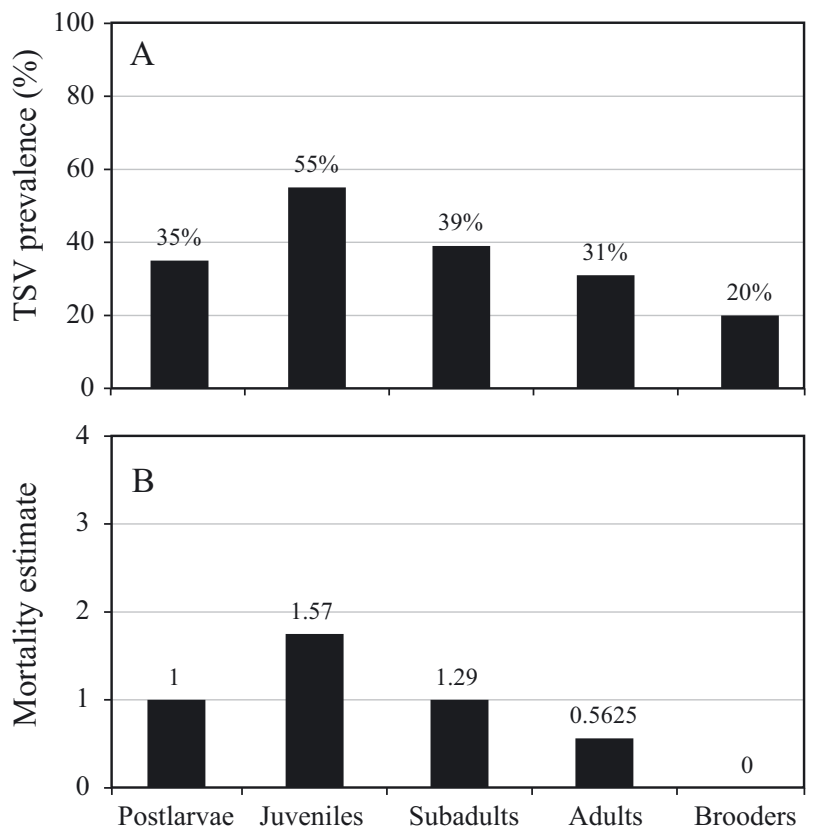

Fig. 2. Litopenaeus vannamei. (A) Average prevalence rates of Taura syndrome virus (TSV) at individual TSV-positive farms. For each TSV-positive farm, the percentage of TSVpositive shrimp (out of 20) was determined and the average was calculated for farms grouped by shrimp growth stages. (B) Average mortality estimates of TSV-positive farms. Mortality rates were estimated by severity level: 0 , no loss; $1,1-25 \%$

loss; $2,26-50 \%$ loss; $3,51-75 \%$ loss; $4,76-100 \%$ loss

the 43 TSV-positive farms, 4 farms had higher than acceptable nitrite levels $\left(>0.25 \mathrm{mg} \mathrm{l}^{-1}\right.$ ) and 3 farms had ammonium levels exceeding the acceptable concentration of $3 \mathrm{mg} \mathrm{l}^{-1}$. No clear correlation existed between TSV infection rates and water quality. However, a significant correlation existed between water quality and mortality rates. The estimated mortality rate score was $1(1-25 \%$ death) for farms with water quality within safety ranges, and 3 (51-75\% death) for farms with water quality outside the safe range. Pond water was also tested to determine whether salinity contributes to TSV infection. No correlation was found between salinity levels and percentages of TSV-positive farms (Fig. 3).

\section{Pathology}

While prominent signs of TSV infection were observed during a previous TSV outbreak in Taiwan (Tu et al. 1999, Yu \& Song 2000), most TSV-positive shrimp collected in this study did not have gross pathology or histopathological lesions. Some of the TSV-positive shrimp with high mortality collected

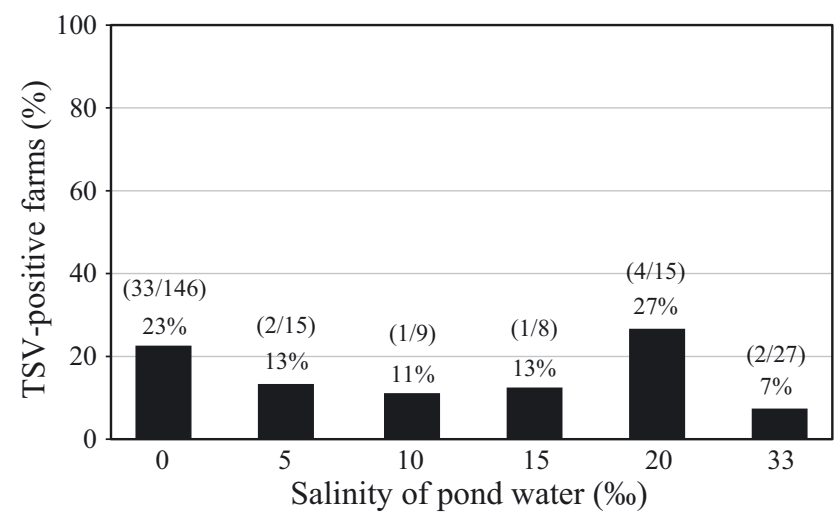

Fig. 3. Litopenaeus vannamei. Correlation between pond water salinity and Taura syndrome virus (TSV) infection prevalence in Pacific white shrimp. Numbers in parentheses indicate number of TSV-positive farms divided by number of farms examined within each water salinity level

from diseased shrimp farms in this study showed significant lesions. Fig. 4A shows the red pigmentation in the tail fans and appendages of TSV-infected white shrimp. On histological examination, TSV lesions appeared as necrosis in the cuticular epithelium of appendages, gills, and tail fans. Of all shrimp that had TSV lesions, $100 \%$ had lesions on the tail fans, $87 \%$ on appendages, and $80 \%$ in gills.

\section{Prevalence of TSV in copepods, Exopalaemon orientis, and dragonfly larvae}

To determine whether other organisms in the farms harbor TSV, samples of Calanus finmarchicus were collected from 20 farms, E. orientis from 10 farms, and dragonfly larvae from 10 farms. The RT-PCR analysis did not detect TSV in any (0/20 farms) Calanus samples or $(0 / 10)$ dragonfly larvae samples, but detected TSV in $10 \%(1 / 10)$ of E. orientis samples (Table 2). Additional samples might be necessary to conclude that tested organisms play no major role in TSV transmission.

\section{Sequence analysis}

The RT-PCR amplification of the TSV VP1 gene (1303 bp) was performed on $8 \mathrm{TSV}$ isolates from collected shrimp and 1 isolate from an Exopalaemon orientis sample. Nucleotide and amino acid sequences of these isolates were compared with TSV sequences in GenBank (Fig. 5). Results indicate that these 9 isolates have $92.3 \%$ nucleotide sequence identity with Venezuelan strain DQ212790 and 99.5\% identity 


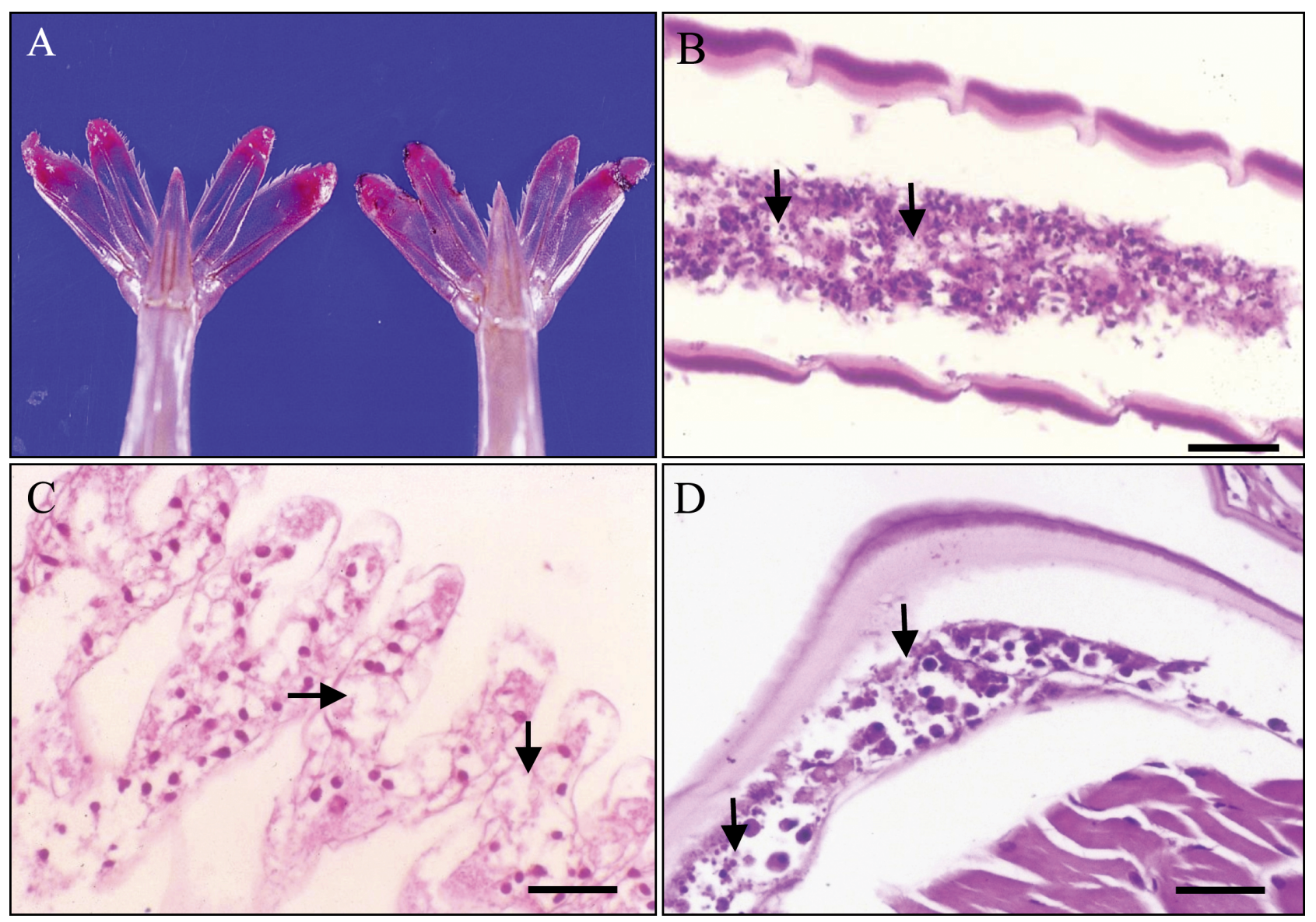

Fig. 4. Litopenaeus vannamei. (A) Red tail fans of moribund Pacific white shrimp from this study. (B-D) Necrosis (arrows) in the cuticular epithelium of (B) appendages, (C) gills, and (D) tail fans of TSV-infected shrimp. Hematoxylin and eosin staining, scale bar $=100 \mu \mathrm{m}$

Table 2. Detection of Taura syndrome virus (TSV) in copepods Calanus finmarchicus, Exopalaemon orientis, and dragonfly larvae by RT-PCR. Shown are the numbers of TSV-positive shrimp farms/numbers of farms examined

\begin{tabular}{|lccc|}
\hline $\begin{array}{l}\text { Sampling } \\
\text { location }\end{array}$ & C. finmarchicus & E. orientis & $\begin{array}{c}\text { Dragonfly } \\
\text { larvae }\end{array}$ \\
\hline $\begin{array}{l}\text { Pingtung } \\
\text { Kaochsing }\end{array}$ & $0 / 10$ & $0 / 5$ & $0 / 5$ \\
Total & $0 / 10$ & $1 / 5$ & $0 / 5$ \\
& $0 / 20$ & $1 / 10$ & $0 / 10$ \\
\hline
\end{tabular}

with Taiwanese strains AF406789 and AY355310. Amino acid sequence identities were $94.5 \%$ and 99.5\% with Venezuelan and Taiwanese strains, respectively. Comparison of the 9 isolates indicates that they had 97.9 to $100 \%$ identity at the nucleotide sequence level and 97.5 to $100 \%$ identity at the amino acid level. When comparing the 8 isolates from shrimp to the 1 isolate from the crustacean sample, identities were 97.9 to $99.8 \%$ at the nucleotide level and 97.5 to $99.8 \%$ at the amino acid level. Sequence of TSV isolated from the E. orientis sample had 99.8\% identity with TSV in shrimp from the same farm, suggesting horizontal transmission. In phylogenetic analysis, a partial sequence of the VP1 gene of the TSV in this study and GenBank accession nos. AY355309, AY355310, AY355311, and AF406789 formed a monophyletic clade with high sequence similarity and a bootstrap value of $98 \%$. Phylogenetic analysis separated the 9 isolates into groups I, II, and III; all 3 groups were grouped with the Asian TSV strains (Fig. 5).

\section{DISCUSSION}

TSV is a significant threat to Litopenaeus vannamei aquaculture, infecting shrimp at all life stages, and killing 40 to $90 \%$ of shrimp (Hasson et al. 1995, Lotz 1997). A TSV outbreak occurred in 1998-1999 in 


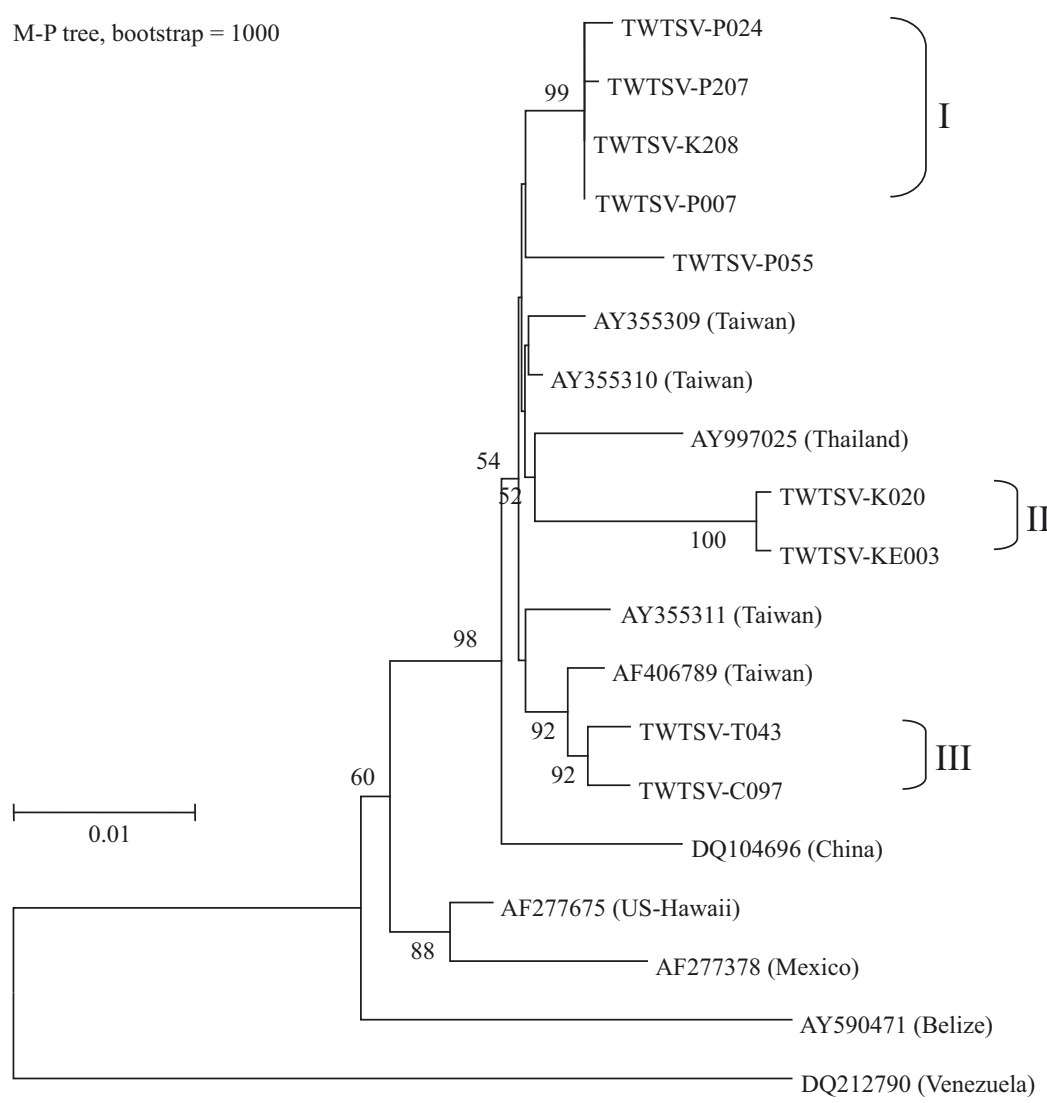

Fig. 5. Phylogenetic tree based on the TSV VP1 gene. Tree topologies were examined by bootstrap analyses using the maximum parsimony method based on 1000 resamplings. Unnoted isolates were from Litopenaeus vannamei in this study. TWTSV-KE003 was isolated from Exopalaemon orientis. Bars indicate genetic distance. Numbers at each node indicate percent bootstrap values. Scale represents 0.01 nucleotide substitutions per position

winter may suggest correlation between temperature and TSV infection, we cannot exclude the possibility that the immune system of host shrimp may be weak during cold months, rendering shrimp more susceptible to TSV infection (Wyban et al. 1995). Interestingly, a recent study determined that under hyperthermic conditions $\left(32^{\circ} \mathrm{C}\right)$, Kona stock Litopenaeus vannamei are resistant to the Hawaii-94 TSV isolate, but not to the Belize strain, suggesting that TSV pathogenesis may be affected by temperatures (Côté \& Lightner 2010).

High concentrations of ammonia and nitrite from intensive farming can also adversely impact the metabolism and immune system of shrimp. Data in this study indicate that while high concentrations of nitrite and ammonia did not increase TSV prevalence, they contributed to mortality of infected shrimps.

This study sequenced the TSV VP1 gene to track the evolution of the virus. A previous study compared the VP2 gene of 40 TSV strains from Belize, China, Columbia, Ecuador, Hawaii, Honduras, Indonesia, Mexico, Taiwan, and Thailand between 1993 and 2004 (Tang \& Lightner 2005). These sequences had a 0 to $5.6 \%$ difference at the nucleotide sequence level and a 0 to $7 \%$ difference at the amino acid

Pingtung County, Taiwan, resulting in massive losses for shrimp farms (Tu et al. 1999). Data collected between 2004 and 2006 indicate a TSV prevalence rate of $20 \%$ in Taiwan's shrimp farms. The TSV prevalence rates for shrimp in various growth stages differed, likely resulting from varying farming practices rather than virus susceptibility. Shrimp from postlarval to adult stages are highly susceptible to TSV infection (Lotz 1997). Thus, steps should be taken by all farms to control TSV spread.

The first TSV outbreak in Taiwan occurred during the winter of 1998-1999 (Tu et al. 1999). The survival rate of infected shrimp was only $10 \%$ during that epidemic. Data in our study also indicate that the highest TSV infection rate of $27 \%$ (15/55 farms) existed during winter (December-February). During the winter months, average TSV prevalence rates at TSV-positive farms were higher at $55 \%$ than in other months. While the high TSV prevalence rate during level. When the VP1 gene sequence was compared, the 9 isolates from the farms had a 0.5 to $7.7 \%$ difference from the 10 strains (from Venezuela and Taiwan) in the GenBank database. Phylogenetic analyses of VP1 of TSV confirmed that 9 isolates in this study were TSV. The evolutionary tree showed that TSV forms a monophyletic clade with GenBank accession nos. AY355309, AY355310, AY355311, and AF406789. This relationship was confirmed by the high nucleotide similarity and bootstrap values. The relatively low mutation rate of TSV (0.5 to $7.7 \%$ genetic variation for the VP1 gene during 1999 to 2006) may contribute to resistance of Litopenaeus vannamei to TSV infection or result in chronic infection.

Currently, no vaccine against TSV exists. Clean environments and stringent selection of a starting crop may help reduce TSV infection rates (Lightner 1999, Samocha et al. 2002). Attention should be paid 
to feed management and possibly farming density during winter. Reduced stress levels and an improved immune system (e.g. by adding $\beta$-glucan to feeds) may reduce crop loss due to infection (Anderson 1992, Su et al. 1995).

Acknowledgements. We thank the Council of Agriculture of Taiwan for financially supporting this research under Contract 97-A-14.2.1-I-B1 (9). T. Knoy is appreciated for his editorial assistance.

\section{LITERATURE CITED}

Anderson DP (1992) Immunostimulants, adjuvants, and vaccine carriers in fish: applications to aquaculture. Annu Rev Fish Dis 2:281-307

Boyd CE (1989) Water quality management and aeration in shrimp farming. Fisheries and Allied Aquacultures Departmental Ser No. 2. Alabama Agricultural Experiment Station, Auburn University, Birmingham, AL

Côté I, Lightner DV (2010) Hyperthermia does not protect Kona stock Penaeus vannamei against infection by a Taura syndrome virus isolate from Belize. Dis Aquat Org 88:157-160

Côté I, Poulos BT, Redman RM, Lightner DV (2009) Development and characterization of a monoclonal antibody against Taura syndrome virus. J Fish Dis 32:989-996

Daniel WW (2005) Biostatistics: a foundation for analysis in the health sciences. John Wiley \& Sons, New York, NY

Felsenstein J (1985) Confidence limits on phylogenies: an approach using the bootstrap. Evolution 39:783-791

Fisheries Agency (2006) Taiwan fisheries yearbook 2006. Council of Agriculture, Executive Yuan, Taiwan

Fitch WM (1971) Towards defining the course of evolution: minimum change for a specific tree topology. Syst Zool 20:406-416

Garza JR, Hasson KW, Poulos BT, Redman RM, White BL, Lightner DV (1997) Demonstration of infectious Taura syndrome virus in the feces of seagulls collected during an epizootic in Texas. J Aquat Anim Health 9:156-159

Hasson KW, Lightner DV, Poulos BT, Redman RM, White BL, Brock JA, Bonami JR (1995) Taura syndrome in Penaeus vannamei: demonstration of a viral etiology. Dis Aquat Org 23:115-126

Hasson KW, Lightner DV, Mohney LL, Redman RM, Poulos BT, White BL (1999) Taura syndrome virus lesion development and the disease cycle in the Pacific white shrimp Penaeus vannamei. Dis Aquat Org 36:81-93

Jukes TH, Cantor CR (1969) Evolution of protein molecules. In: Munro HN, Allison JB (eds) Mammalian protein metabolism. Academic Press, New York, NY, p 21-132

Kureshy N, Davis DA (2002) Protein requirement for maintenance and maximum weight gain for the Pacific white shrimp, Litopenaeus vannamei. Aquaculture 204:125-143

Liao IC (1989) Penaeus monodon culture in Taiwan: through two decades of growth. Int J Aquac Fish Technol 1:16-24

Lightner DV (1996) A handbook of shrimp pathology and diagnostic procedures for diseases of cultured penaeid shrimp. World Aquaculture Society, Baton Rouge, LA

Lightner DV (1999) The penaeid shrimp viruses TSV, IHHNV, WSSV, and YHV: current status in the Americas, available diagnostic methods, and management strategies. J Appl Aquac 9:27-52

Lightner DV, Redman RM, Hasson KW, Pantoja CR (1995) Taura syndrome in Penaeus vannamei (Crustacea: Decapoda): gross signs, histopathology and ultrastructure. Dis Aquat Org 21:53-59

> Lo CF, Kou GH (1998) Virus associated white spot syndrome of shrimp in Taiwan: a review. Fish Pathol 33:365-371

$>$ Lotz JM (1997) Effect of host size on virulence of Taura virus to the marine shrimp Penaeus vannamei (Crustacea: Penaeidae). Dis Aquat Org 30:45-51

> Mayo MA (2002) A summary of taxonomic changes recently approved by ICTV. Arch Virol 147:1655-1663

> Menz A, Blake BF (1980) Experiments on the growth of Penaeus vannamei Boone. J Exp Mar Biol Ecol 48:99-111

Nunan LM, Poulos BT, Lightner DV (1998a) Reverse transcription polymerase chain reaction (RT-PCR) used for the detection of Taura syndrome virus (TSV) in experimentally infected shrimp. Dis Aquat Org 34:87-91

Nunan LM, Poulos BT, Lightner DV (1998b) Reverse transcription polymerase chain reaction (RT-PCR) used for the detection of Taura syndrome virus (TSV) in experimentally infected shrimp. Dis Aquat Org 34:87-91

Overstreet RM, Lightner DV, Hasson KW, McIlwain S, Lotz JM (1997) Susceptibility to Taura syndrome virus of some penaeid shrimp species native to the Gulf of Mexico and southeastern United States. J Invertebr Pathol 69:165-176

Poulos BT, Noble BW, Lightner DV (2008) Comparison of Taura syndrome virus (TSV) detection methods during chronic-phase infection in Penaeus vannamei. Dis Aquat Org 82:179-185

Rzhetsky A, Nei M (1993) Theoretical foundation of the minimum-evolution method of phylogenetic inference. Mol Biol Evol 10:1073-1095

> Saitou N, Nei M (1987) The neighbor-joining method: a new method for reconstructing phylogenetic trees. Mol Biol Evol 4:406-425

Samocha TM, Hamper L, Emberson CR, Davis AD, McIntosh D, Lawrence AL, Van Wyk PM (2002) Review of some recent developments in sustainable shrimp farming practices in Texas, Arizona, and Florida. J Appl Aquac 12:1-42

Su MS, Liu KF, Chang CF, Liao IC (1995) Enhancement of grass prawn Penaeus monodon postlarvae viability by beta-1,3-glucan from Schizophyllum commune. J Taiwan Fish Res 3:125-132

Tang KF, Lightner DV (2005) Phylogenetic analysis of Taura syndrome virus isolates collected between 1993 and 2004 and virulence comparison between two isolates representing different genetic variants. Virus Res 112:69-76

Tu C, Huang HT, Chuang SH, Hsu JP and others (1999) Taura syndrome in Pacific white shrimp Penaeus vannamei cultured in Taiwan. Dis Aquat Org 38:159-161

> Wertheim JO, Tang KF, Navarro SA, Lightner DV (2009) A quick fuse and the emergence of Taura syndrome virus. Virology 390:324-329

- Wyban J, Walsh WA, Godin DM (1995) Temperature effects on growth, feeding rate and feed conversion of the Pacific white shrimp (Penaeus vannamei). Aquaculture 138:267-279

> Yu CI, Song YL (2000) Outbreaks of Taura syndrome in Pacific white shrimp Penaeus vannamei cultured in Taiwan. Fish Pathol 35:21-24 